\title{
AZ ATOMERŐMÜ A DUNA BAL PARTJÁRÓL NÉZVE
}

\author{
(The Nuclear Power Plant as Seen from the Left Bank \\ of the Danube)
}

KOVÁCS ANTAL

Kulcsszavak:

atomerōmû lakossági támogatottság társadalmi felelösségvállalás (CSR)

A Paksi Atomerömü biztonságosan olcsón és nagy mennyiségben állit elö villamos energiát, ezzel fontos szerepet betöltve hazánk elektromos áramellátásában. Ma a megfelelö müszaki és gazdasági háttér nem elegendö a hosszú távú sikerhez, hiszen egy demokráciában nem müködhet egy iparvállalat sem lakossági támogatottság nélkül. A tanulmányban az erömü és a környezö lakosság kapcsolatát mutatjuk be összefoglalva az atomerömũ erôfeszitéseit, eredményeit a lakossági kapcsolatok javitása érdekében.

\section{Bevezetés}

A 21. század talán legfóbb kérdése, hogy az emberiség képes lesz-e megfelelő választ adni a klímaváltozás kihívásaira, ki tudja-e elégíteni a globális szinten egyre növekvő energia-éhséget úgy, hogy az üvegházhatású gázok kibocsátását elfogadható szintre csökkentse. Úgy tünik, nincs egyetlen olyan primer energiaforrás, amely képes lenne maradéktalanul kielégíteni az igényeket, inkább az energiaforrások kombinációja jelenthet megoldást. Világszerte egyre inkább a megoldás egyik kulcsszereplójének tekintik az atomenergiát. A nukleáris energiával szemben azonban fenntartása van az emberek egy jelentős részének, megfelelő támogatottság hiányában pedig nem lehet egy demokráciában atomerómüveket építeni, múködtetni (Elter et al 2006).

Magyarország villamosenergia-ellátásának legjelentősebb szereplője az atomerőmü, a hazai áram közel 40\%-a innen származik, s a jövő is nehezen képzelhető el hazánkban atomenergia nélkül. A cikkben megvizsgáljuk az erőmủ jelenlegi helyzetét, lehetôségeit, feladatait, elsősorban a tájékoztatás terén. Az európai és hazai helyzet feltárásához több felmérés nyújt segítséget. Rendelkezésre állnak az Eurobarometer idevonatkozó felmérései, $\mathrm{s}$ az atomerőmü saját vizsgálatainak eredményei is.

\section{A támogatottság}

A Paksi Atomerỏmü támogatottsága évek óta itthon stabilan 70-75\% körül mozog. Ez az eredmény Európában kiemelkedőnek számít - hasonló támogatottságot csak Svédországban mértek (Attitudes towards... 2006) -, ugyanakkor az erőmü 
közelében élök közül azok, akik a Duna bal partján laknak, az országos átlag alatt szimpatizálnak az atomenergiával (Regionális... 2006). Ez annál is érdekesebb, mert az erőmủ jelentős összegeket költ arra, hogy a lakosságot megfelelő módon tájékoztassa, s az önkormányzatokat, civil szervezeteket támogassa. Mi lehet akkor ennek a viszonylag alacsonyabb támogatottságnak az oka?

$\mathrm{Az}$ erőmủ folyamatosan komoly kihívásokkal néz szembe, s megállapítható, hogy eddig sikeresen teljesitette valamennyi célkitüzését, akár müszaki, akár tájékoztatási, lakossági kapcsolatok szintjén vizsgáljuk is azokat. 2006-ban sikerrel megtörténtek az üzemidő-hosszabbítással (ÜH) járó közmeghallgatások, s a tervek ellen komoly kifogás nem merült fel a környező lakosság részéről (Kováts 2006a). Ugyanakkor figyelembe kell venni, hogy az ÜH még nem valósult meg (2012-tôl beszélhetünk meghosszabbított üzemidőről az 1. blokk esetében), valamint azt is, hogy az ÜH támogatása nem egyenlö az új blokkok építésének támogatásával. A közvélemény-kutatások szerint ma nincs meg az ehhez szükséges támogatás még a környező településeken sem, pedig a szakemberek az 5., 6., blokk építését már komolyan számításba vették, hiszen az EU elvárásait, a hazai kapacitásokat, valamint a hazai igénybővülést figyelembe véve ésszerủ megoldást csak az atomenergia jelenthet (Csom 2006; 2007).

Miután egy ilyen beruházás hosszú idö alatt valósulhat meg, ha 2020-ban szeretnénk a hálózatra kötni az új blokkokat, 2010 körül már meg kell hoznunk a megvalósitásra vonatkozó döntéseket (Poós-Rátz 2005). Már jeleztük, hogy ma a sokrétü és komoly nagyságrendü támogatás és informálás ellenére sem lenne elegendő a lakossági támogatás a beruházások megkezdéséhez. A negatív beállítódások, attitüdök, hiedelmek nem változtathatók meg azonnal, ehhez évek kellenek. Ahhoz tehát, hogy a mélyen gyökerező beállitódásokat kedvezővé változtassuk, elöször meg kell ismernünk azokat.

\section{Azonos sokaság, kicsit eltérö kérdések, nagyon eltérö eredmények}

$\mathrm{Az}$ atomerỏmủ számára az egész ország támogatása fontos, de természetesen a legfontosabb a környező lakosság szimpátiája, ezért is végeztet minden évben regionális közvélemény-kutatást. A 2006. év végi kutatást kiegészítettük egy külön a Duna bal partján élőket vizsgáló mintára vonatkozó kérdéssorral, mely segítségével behatóbb képet kaphatunk az ottani lakosság gondolkodásáról.

Három különböző vizsgálat áll rendelkezésünkre:

2006 végén készült el a Szociográf $\mathrm{Kft}$. szokásos év végi regionális felmérése (Regionális... 2006), nyári aktuális állapotot mért a TNS (Felmérés... 2006), s a 2007 januárjában megjelent Eurobarometer is nyári eredményeket közöl az EU és benne természetesen Magyarország lakosságának az energiahelyzettel, atomenergiával kapcsolatos véleményérỏl (Attitudes on... 2007). A három felmérés hasonló sokasággal és módszertannal, viszont eltérö kérdéssorral dolgozott, de vannak közös pontok, melyek segítenek az adatok összehasonlításában. 
Induljunk ki a legáltalánosabb kérdésből, az atomenergia támogatottságából. A magyar sajtó tele volt 2007. január elején a hírrel, miszerint az Eurobarometer felméréséből az derül ki, hogy „a magyarok 34\%-a támogatja az atomenergiát”" (Attitudes on... 2007). Ez az eredmény nagyon távol áll attól, amit a TNS mért (76\%) (Felmérés... 2006), holott a két vizsgálat időben nagyon közel volt egymáshoz. Az európai kutatás 2006. május-júniusára, a magyar 2006 júliusára esett. Az egy évvel korábbi Eurobarometer felmérés is 65\%-os támogatottságot mért hazánkban (Radioaktiv... 2005). A hatalmas különbséget a kérdésfeltevés módja és annak értékelése okozza. A 34\% helytálló eredmény, de ez csak azok véleményét tartalmazza, akik kifejezetten preferálják az atomenergiát, s hallgat arról a 42\%-ról, akik - bár nem kifejezetten támogatják -, de elfogadják, nem ellenzik a nukleáris energia felhasználását. Mindössze 20\% azok aránya, akik ellenzik az atomenergiát. A hazai sajtó elmulasztotta megjegyezni, hogy a támogatók, s a ,nem ellenzők" együtt 76\%-ot tesznek ki, $\mathrm{s}$ ez az érték pontosan megegyezik a TNS felmérésében észleltekkel. Napokig azonban a 34\%-os adat hallatszott, s ez valószinüleg negativ irányba hatott a támogatásra, kétségeket ébreszthetett az atomerỏmủ által évek óta emlegetett 75\% feletti támogatás hitelességét illetően.

A hazai cikkek kiemelték, hogy az ország megújuló forrásokat akar 80\%-os támogatottság mellett, ugyanakkor a vizsgálatokban kimutatható másodlagos preferenciákról nem tesznek említést. Az Eurobarometer felméréséből kiderül, hogy az EU-s polgárok többsége s így hazánk lakói is az energiakérdéssel kapcsolatban legfontosabbnak az alacsony árat és a megfelelő ellátásbiztonságot tartják, harmadik helyen szerepel a környezetvédelem (Attitudes towards.. 2006). Ez egyértelmủen mutatja, hogy az emberek igényeinek leginkább megfeleló energiaforrás a nukleáris energia (noha ennek láthatóan nincsenek is tudatában).

A másodlagos és a kinyilvánított preferenciák látványos eltérését a hiányos, illetve a téves ismeretek okozzák. Ez több okra vezethető vissza. Az egyik ok az, hogy az EU-s polgárok - egyelőre - nem tartják különösebben fontosnak az energiakérdést. Az Eurobarometer felmérése arra is kitért, hogy megvizsgálta, melyek a polgárokat leginkább foglalkoztató problémák a saját országuk szempontjából. A felvetett problémák között csak sokadikként szerepeltek az energiával kapcsolatos gondok, s sajnálatos módon a környezetvédelem még kisebb fontossággal bír (Energy... 2007).

Érdekes, hogy egy másik vizsgálat szerint, mely a Föld szintjén vizsgálta az embereket leginkább foglalkoztató kérdéseket, - a terror, háborúk, gazdasági problémák elött - a globális felmelegedést sorolták a legfontosabb helyre. Látható, hogy amíg a globális helyzetről van szó, akkor nagy súlyt kap a környezetvédelem, mihelyt azonban a lokális szintre érünk, ahol esetleg cselekedni kellene, már nem tulajdonítunk akkora jelentőséget neki.

A másik ok az lehet, hogy a nyugat-európai politikai elit egy része hosszú éveken keresztül kovácsolt politikai tőkét az atomenergia-ellenes jelszavakkal, aminek az lett a következménye, hogy egyes országokban a polgárok meg sem hallják az információkat, erős prekoncepciókkal élnek, melyek eleve kizárják a valós információk elfogadását. Ezen országok politikai vezetöi többségében azóta már belátták, hogy 
az atomenergia nélkül nem oldható meg országuk biztonságos energiaellátása, ezért revideálták álláspontjukat, most viszont meg kell küzdeniük a korábban (általuk is) gerjesztett társadalmi atomellenességgel.

Magyarországon láthatóan ennél kedvezöbb a helyzet, mindössze $20 \%$ körül van az atomenergiát elutasítók aránya. Vizsgáljuk meg közelebbről a hazai helyzetet!

\section{Országos - regionális támogatottság}

Érdemes figyelmet szentelni az országos és a regionális eltérések nagyságára és előjelére (1.ábra). Miután a szükebb régió meghatározó szereplöje az atomerömü, ami közvetve több mint tízezer embernek ad munkát, jogosnak tủnik a várakozás, hogy a támogatottság helyi szinten meghaladja az országos értékeket. Ez azonban csak részben van így. A Duna jobb partján élők körében a várakozásoknak megfelelỏen magas az elfogadottság, támogatottság (munkahelyek, városfejlesztés, iparúzési adó stb. következtében). Viszont az erómü évek óta küzd a Duna bal partján, az erőmủ közelében élők támogatásának növelése érdekében, de a kívánt támogatottságot nem sikerült elérni, annak ellenére, hogy az atomerömü a vállalati társadalmi felelösségvállalásban (CSR) is jeleskedik.

\section{1. ÁBRA}

Népszavazás esetén az új blokkok támogatottsága

(The Support of New Units in Case of a Referendum)

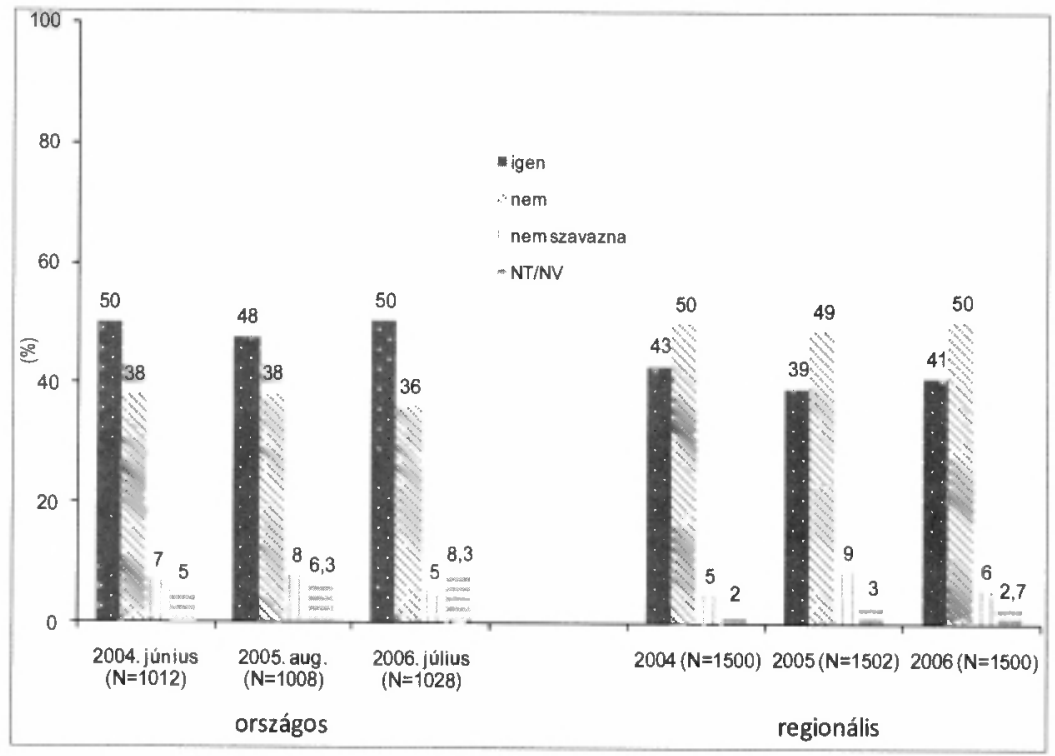

Forrás: A Paksi... (2006). 


\section{Az atomerömü támogatási rendszerének fejlödése}

Sokáig, az 1980-as évek elején történt üzembe helyezés óta mintegy 20 évig, élt az erőmü az ad hoc támogatások rendszerével. Még ma is 300-500 levél érkezik évente, amelyek segítséget, támogatást kérnek a legkülönbözöbb célokra. Az erőmű vezetése mérlegel, $\mathrm{s}$ általában a legindokoltabb $20-25 \%$ teljesítésre kerül. Legyen bár szó egy parókia ereszcsatornájának megjavításáról, közintézmény létesítéséről vagy templomépítésről (Kováts 2006b).

\section{Információs társulások - ủj utak}

A 1990-es évek során megalakult információs társulások létrejöttében az atomerőmü segédkezett, $\mathrm{s}$ az azok müködéséhez szükséges anyagi és információs hátteret biztosítja. A Társadalmi Ellenőrző és Információs Társulás (TEIT) az atomerömü körüli települések szervezete, a Társadalmi Ellenőrző és Tájékoztató Társulás (TETT) a bátaapáti tároló épitése kapcsán érintett hét település társulata, a NyugatMecsekben létrejött Társadalmi Információs Társulást (NyMTIT) pedig a majdan itt létesülö kiégett kazetták földalatti tárolója megépítése kapcsán érintett települések alkotják. Az Információs Izotóp Társulás (IIT) a püspökszilágyi radioaktív hulladéktároló körüli hét település összefogásának eredménye.

A települések ilyen jellegủ támogatásán, az alkalmi segítségnyújtásokon túl az erőmủ kereste a még hatékonyabb és kiszámíthatóbb támogatási rendszer kialakításának lehetőségét. A térségek problémáinak elemzése megmutatta, hogy a települések pályázatai az önerỏ hiánya miatt buknak meg. Ekkor, 2001-ben az erömü - országosan egyedülálló támogatási lépésként - 30M Ft támogatást adott a PaksDunaföldvár Kistérségi Társulásnak, mely támogatást kizárólag térségfejlesztési pályázatok önrészeként használhatták fel. Az új támogatási forma sikeresnek bizonyult, hiszen minden forintnyi támogatás további $4-5 \mathrm{Ft}$ fejlesztési pénzt eredményezett. A siker egyik záloga az volt, hogy a helyi polgármestereken kívül az erőmü szakemberei és az országgyủlési képviselők együttesen hozták meg a döntéseket a pályázatokat illetően. A sikeres pályáztatást rendben megvalósuló programok követték, ezért az atomerỏmủ kiterjesztette a Duna bal partjára is a pályáztatást. Nyilvánvalóvá vált, hogy az erőmú képes - az olcsó és biztonságos villamos energia elöállításán túl - olyan programok koordinálására, végrehajtására, amelynek érzékelhető gazdasági eredményei lesznek.

Elkezdődött az erőmủ napi mủkődésétől független képzések beindítása, ezzel segítve az erőmú környezetében élök felkészítését az újabb kihívásokra. 50 kistérségi és önkormányzati szakember tanult a 12 napos kurzuson, amelynek költségét az erőmủ állta. A számos tanfolyam közül ki kell emelni a „Vállalkozásindítási és -múködtetési ismeretek" kurzus megszervezését és lebonyolítását, mely egyidejüleg Pakson és Bátaapátiban történt. A több mint 3 hónapos képzésen $2 \times 15$ fö vett részt, közưlük jó néhányan már be is indították vállalkozásukat az erőmü segítségével. 
Az erömü nem elégedett meg egy elméleti oktatással, valódi, gyakorlatban is használható eredményt akart elérni. A tanfolyamot Anglia legsikeresebb szakirányú cége irányította, átadva több évtizedes tapasztalatait. A tanfolyamot elvégzők számára további konzultációkat biztosít az erőmủ, egy-másfél évig „fogva a kezüket”. Többeknek sikeresen beindult a vállalkozása, melyhez az erőmủ a továbbiakban bemutatásra kerülő módon pályázati forrásokat is biztositott.

\section{Duna-Mecsek Területfejlesztési Alapitvány}

Az erömü folyamatosan bővítette azon tevékenységeinek körét, melyek a fỏ tevékenységen túl a társadalomnak más módon is hasznára válnak. A 2001-es paksi és az azt követö kalocsai kistérségi támogatások sikerei felvetették a segítségnyújtások további bővítésének lehetôségét (Kováts 2006a). Az atomerőmü számára nehéz feladatot jelentett annak meghatározása, hogy milyen körben, s milyen preferenciával adja a támogatásokat, az elosztás módját, $\mathrm{s}$ a támogatandó célokat.

A kérdések megválaszolásához, a döntéshez az atomerỏmú felkérte az MTA Regionális Kutatások Központja Dunántúli Tudományos Intézetét, hogy készítsen egy elemzést az érintett térségekről, s tárja fel a lehetséges fejlesztések irányait. Az elkészült tanulmány igen sokrétü, hiszen megvizsgálta az érintett térségek gazdasági, agrárgazdasági helyzetét, értékelte a turizmus, a humán erőforrások, az infrastruktúra lehetöségeit, vizsgálta a környezeti állapotokat, a környezetvédelmet, környezetfejlesztést. Több változat is született a kedvezményezettek körének megállapítására. Természetesen egyrészt a minél több érintett bevonása a cél, másrészt a támogatások túlzott elaprózása az elegendỏnél kisebb hatást fejtene ki.

A hazai nukleáris létesitmények környezetében és az új tároló helyek kutatásában érintett térségek közvetlen környezete: Paks, Kalocsa, Bátaapáti, Boda és Püspökszilágy térsége. Ez összesen 60 települést, mintegy 140 ezer lakost érint. A nukleáris településkörzetek, pontosabban térségek a Duna mellett, illetve a Mecsek lábánál helyezkednek el, ebből logikusan adódott az alapítvány elnevezése: DunaMecsek Területfejlesztési Alapítvány, mely 2006 áprilisában kezdte meg müködését. Az alapító, a Paksi Atomerőmủ Zrt. évi 500 millió forintot bocsát az alapítvány rendelkezésére. Az alapítvány célja a település-, térség- és gazdaságfejlesztés. A területi lehatárolás után meghatározásra került a támogathatók köre: az önkormányzatok, azok társulásai, intézmények, közhasznú szervezetek, civil szervezetek, egyesületek, gazdálkodó szervezetek.

2006-ban és 2007-ben két-két alkalommal írták ki a pályázatot, melyeket rendben elbíráltak, így lehet egy rövid értékelést adni az első két év tapasztalatairól.

Az első kör pályázatain látható, hogy a pályázók még nem pontosan értették meg az alapítvány céljait. A pályázatok által kért összeg magas volt, közel egy milliárd $\mathrm{Ft}$, a kiosztott támogatás 234M Ft körüli érték. Egy forintnyi benyújtott igényre kb. 24 fillér megítélt támogatás jutott, a második fordulóban ez az érték 23 fillér, tehát itt sem találunk jelentős eltérést. Mint már jeleztük, nehéz értékelést készíteni a megvalósulás 
ellenőrzése nélkül, s az alapítvány preferált célkitủzései közül a térségi kohézió erősítése, illetve a turizmus fejlesztése is majd csak hosszabb távon értékelhetö, de az új munkahelyek létrejötte már most számszerüsíthetö. A második fordulóban a kisebb megitélt támogatás, kb. 156M Ft lényegesen nagyobb számú új munkahely megteremtését segitette elő. Az első fordulóban 23, a másodikban 64 új munkahely jöhetett létre. Egy új állás létrehozására jutó támogatás összege $10,1 \mathrm{M} \mathrm{Ft}$, illetve 2,43M Ft volt.

2007. évben a Kuratóriumhoz 88 pályázat érkezett, amelybỏl 46 részesült támogatásban. Az igényelt támogatás összege $1080005184 \mathrm{Ft}$ volt, amelyből több mint $381 \mathrm{M}$ Ft odaítéléséröl döntött a testület. A megitélt támogatás közvetetten több mint három milliárd Ft fejlesztést generált az érintett térségekben. A 2007. évben támogatott pályázatok elsősorban munkahelyteremtésre, gazdaságfejlesztésre, a helyi turisztikai vonzerők fejlesztésére, valamint a területi kohéziót elösegítő fejlesztésekre irányultak. A támogatottak között szerepelnek önkormányzatok, önkormányzati társulások, közhasznú szervezetek, egyesületek, valamint gazdálkodó szervezetek. Az alapítvány segítségével 90 új munkahely létesülésére nyílott lehetöség, tehát a 2006-os év munkahelyteremtő lendülete tovább folytatódott.

Az adatokból látszik, hogy az érdekeltek többsége megértette az alapítvány céljait, gyorsan reagált az új helyzetre. Ugyanakkor a pályázatokat áttekintve megállapítható, hogy jelentős eltérések vannak az egyes térségek között. A korábbi évek gyakorlata elkényelmesítette a térségek vezetőit, hiszen nem kellett különösebbet tenni azért, hogy erömü-támogatásokhoz jussanak. Az alapítvány nem titkolt célja, hogy versenyre $\mathrm{s}$ hatékonyabb felhasználásra kényszerítse az érintetteket. Azok a térségek, amelyek nem pályáznak eleget, vagy nem elég jól, azok saját lehetőségeiket szủkítik le. Érezhetỏ a polgármesterek némi ellenérzése azzal kapcsolatban is, hogy míg eddig szinte minden támogatás rajtuk keresztül történt, addig most civilek, lakossági vállalkozások is közvetlenül pályázhatnak az alapítványhoz. Az önkormányzatok fontos feladata, hogy megismertessék a lehetőségeket, és támogassák a pályázatok elkészítésében polgáraikat, vállalkozásaikat.

\section{Erős támogatás - gyenge támogatottság?}

Vizsgálatot végeztünk annak érdekében, hogy megtudjuk, mi áll a Bács-Kiskun megyeiek elutasító véleménye mögött. Természetesen adódik egy válasz, hogy miközben az erőmủ közelsége a kockázat mértékét tekintve a paksi oldallal összemérhető, addig a pozitív hatások (munkalehetőség, iparüzési adó, infrastruktúrafejlesztések) töredéke jut a túlsó partra, viszont a fent ismertetett támogatási rendszer éves szinten több százmillió Ft támogatást jelent a Bács-Kiskun megyei településeknek. E támogatások mellett az atomerőmünek érezhető káros hatása nincs a területre, hiszen korábban megvizsgáltatta az erőmủ, hogy van-e bármi kihatással az alföldi oldal mezőgazdasági termékei iránti keresletre a létesítmény közelsége. $\mathrm{Az}$ eredmények egyértelmủen kizárták az ilyen kapcsolatot. A kézzelfogható elönyök és a nem létező hátrányok ellenére mégis alacsony a támogatottság. Az atom- 
erőmủ jövője szempontjából kiemelten fontos, hogy a közvetlen környezetében megfelelően támogassák, ehhez viszont elöbb meg kell ismerniük a célcsoportot, hiszen üzenetei, akciói, támogatásai sokkal hatékonyabbak lesznek, ha azon a csatornán, abban a stílusban és olyan módon jutnak el a célcsoporthoz, amelyre az leginkább fogékony. Ezért az erőmü által megrendelt szokásos év végi regionális kérdöív kiegészítéseként az alföldi részen élőknek plusz 10-12 kérdést is feltettünk.

A kérdéssor összeállításának előkészítése érdekében végeztettünk egy minifókuszcsoportos vizsgálatot. Ehhez az Alföldröl az erőmủbe bejáró dolgozók segitségét vettük igénybe. A jelenleg 2800 PA Zrt-s munkavállaló közül mindössze 5 (!) jár a Duna másik oldaláról dolgozni. A fókuszcsoportos beszélgetés és a kérdóíves felmérés eredményeit nem külön-külön, hanem együtt értékeljük, esetenként utalva az országos vizsgálati eredményekre.

A kérdéssor több szempontból igyekszik vizsgálni az érintett népességet, ezek közül számunkra legfontosabb az erőmúhöz füződő viszony. A többi kérdés az okokat járja körül.

Sajnos a válaszok nem túl bíztató eredményt mutatnak Magyarország következő 25 évre vonatkozó atomprogramjával kapcsolatban. E szerint azok, akik ,más fütőanyagú erỏmủvek építésével fokozatosan leállítanák a Paksi Atomerőmủ blokkjait a tervezett üzemidő lejárta elött 2010-ig”és azok akik „Gyors ütemben leállítanák a paksi blokkokat, akár energiaimport árán is” együttesen 48,4\%-ot tesznek ki. A válaszok alapján többen vannak a régióban, akik a tervezett üzemidő elött bezárnák az eröművet, mint azok, akik tovább üzemeltetnék, illetve új blokkokat építenének (47\%). Másként fogalmazva a kérdést más választ kapunk.

Egy, az üzemidő-hosszabbításról szóló esetleges népszavazás alkalmával a következő eredmények születnének:

- támogatná

- nem támogatná

- nem tudja / nem válaszol

$\begin{array}{rr}744 \text { fo } & 49,6 \% \\ 671 \text { fö } & 44,7 \% \\ 85 \text { fö̀ } & 5,7 \%\end{array}$

Látható, hogy - bár a többség az ÜH mellett van -, mégsem elég magas a támogatói arány.

Érdekes különbséget mértünk az új atomerőmủ támogatottságát illetően attól függően, hogy általában egy új atomerőmủről, vagy a paksi bővítéséről volt-e szó.

Az elvi egyetértés kérdése
- egyetértene
437 fơ
$29,1 \%$
- nem értene egyet
1018 fö
$67,9 \%$

Ha azonban paksi telephellyel vetjük fel a kérdést, lényegesen kedvezőbb képet kapunk.

$$
\begin{aligned}
& \text { - támogatná } \\
& \text { - nem támogatná } \\
& \text { - nem szavazna }
\end{aligned}
$$

$41,1 \%$ $50,4 \%$ $5,8 \%$

Az új atomerömü kevéssé vonzó a polgároknak, azonban az adatokból látható, ellenállásuk csökken, ha Paks neve is az épülendö atomerömủ mellé kerül. Ez azt 
mutatja, hogy az emberek igazából megbíznak a Paksi Atomerömü biztonságában. A kérdőív további kérdései is igazolják ezt a megállapítást, hiszen a többség $(80 \%)$ gondolja szigorúnak, megfelelőnek a biztonsági elöírásokat, hasonló arány gondolja úgy, hogy ezeket be is tartják. A válaszadók mindössze $20 \%$-a vélekedik úgy, hogy az erömü nem felel meg az EU-s elvárásoknak.

A különböző módon feltett hasonló tartalmú kérdésekre eltérö válaszokat kaptunk, azt azonban el kell fogadnunk, hogy jelenleg az atomerỏmü környezetében mért támogatottság nem olyan mértékủ, mint azt az atomerỏmủ hasznossága indokolná. A különböző méréseredmények megmutatták, hogy mennyire fontos a kérdés megfogalmazásának milyensége, $\mathrm{s}$ ezzel egyben felhívja a figyelmet az ebböl adódó kiszolgáltatottságra. Új blokkok épitésével kapcsolatban a polgárok többsége népszavazást tart szükségesnek (2. ábra), amit, ha valamelyik ellenzö csoport kezdeményezne, várhatóan egy nekik kedvezően megfogalmazott kérdéssel számunkra kedvezőtlen képet tudna produkálni.

\section{2. ÁBRA}

Egy üj atomerömü létesitéséhez szükségesnek tartott társadalmi feltételek

(The Social Conditions Considered Neccesary for the Building of a New Power Plant)

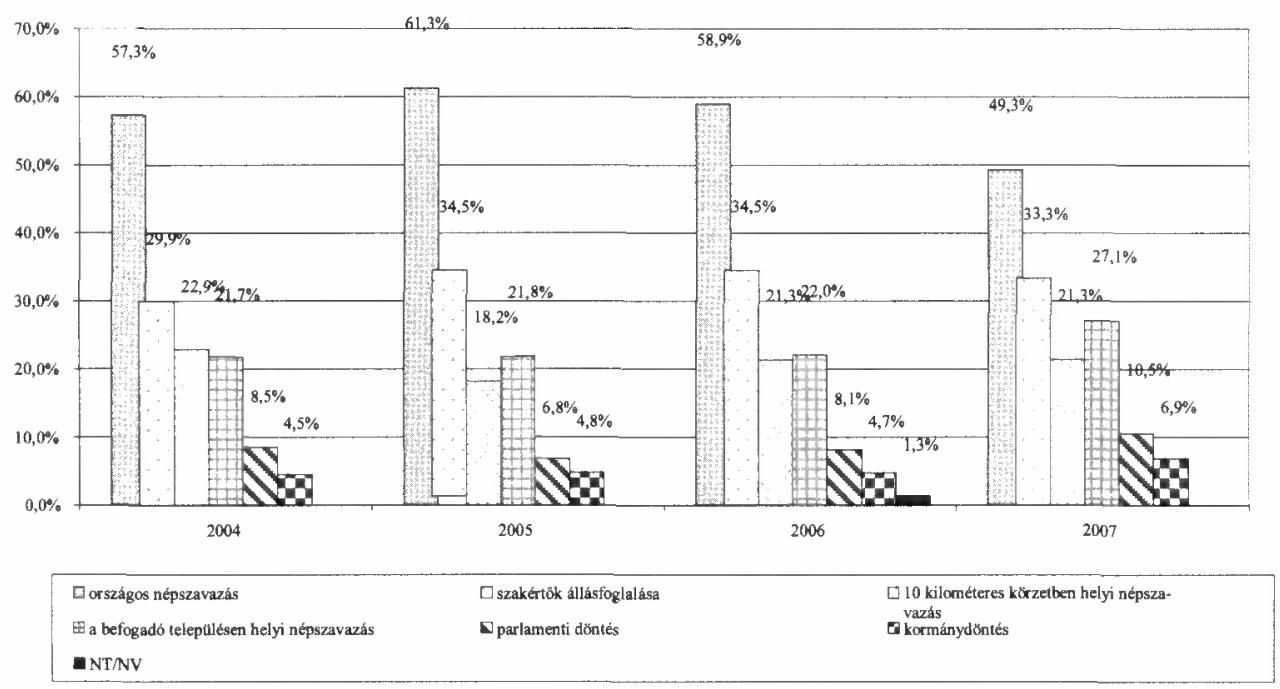

Forrás: Szociográf (2006).

További kiszolgáltatottságot jelent, hogy rajtunk kívülálló okok is felkorbácsolhatják a kedélyeket. Ha bárhol a világban történik valami negatív esemény az atomenergiával kapcsolatban - még ha az nem is igazán komoly jelentöségü -, akkor abból azonnal tỏkét kovácsolhatnak a nukleáris energia ellenzöi, $\mathrm{s}$ akcióikkal akár az ÜH-val kapcsolatban is károkat okozhatnak. 


\section{A jobb part túl messze van}

A Duna bal partján élök ellenérzéseivel kapcsolatban négy fö problémakört sikerült azonosítani, ezek közül a tájékoztatás és a munkalehetőség kérdésével részletesebben, míg az egészséggel és a polgármesteri hivatalok müködésével - terjedelmi okok miatt - csak érintölegesen foglalkozunk

\section{Tájékoztatás}

A tájékoztatás feladatát két részre lehet bontani. Egyik az atomenergiával, az energiahelyzettel, ezen belül a Paksi Atomerömü Zrt.-vel kapcsolatos ismeretek átadása, terjesztése. Itt kell bemutatni, hogy miért kell az atomerőmü, miért használja növekvő mértékben a világ, $s$ miért jó nekünk, magyaroknak.

A másik - nem kevésbé fontos - feladat a régió polgáraiban tudatosítani, mit tesz az erỏmủ a régió, $\mathrm{s}$ azon belül az egyes települések érdekében.

\section{Az energiahelyzet, az atomenergia szerepe a világ és az ország energiaellátásában}

A kérdőív vizsgálta a lakosság ilyen irányú tájékozottságát. Az emberek többsége még mindig úgy tudja, hogy az atomenergia hozzájárul a globális felmelegedéshez, és mindössze $42,3 \%$ ismeri a tényeket. Ez az arány Bács-Kiskun megyét tekintve még sokkal rosszabb.

A Duna bal partján élő embereknek alig több mint a fele tud csak arról, hogy a Paksi Atomerömủ üzemidejét jelentős mértékben meg kívánják hosszabbítani.

$\mathrm{Az}$ erőmü által kiadott tájékoztató fuizet hatását is vizsgáltuk. A megyében élők mindössze 12,4\%-a találkozott a kiadvánnyal. Ez azt mutatja, hogy a terjesztés módját át kell gondolni. A kiadvány minőségére jellemzó, hogy aki megkapta, azok közül ötböl négyen elolvasták. Ez viszont jó aránynak tekinthetö.

$\mathrm{Az}$ elöállított villamos energia költségeire vonatkozóan megállapítható, hogy regionális szinten a válaszadók alig több mint fele (52\%) véli úgy, hogy az atomerőmủ a legolcsóbb elóállító. Megfigyelhetö, hogy míg az elmúlt két év alatt 10 százalékpontot csökkent az atomenergiát helyesen a legolcsóbbnak gondolók aránya, addig közel duplájára, 14-ről 27,7\%-ra nött azok aránya, akik a megújuló forrásokat tartják a legolcsóbbnak (A Paksi... 2006).

Vizsgáltuk a polgárok véleményét az erömủ egészségre gyakorolt hatását illetően is. A Duna bal partján élök közül tízből négyen hiszik, hogy erösen egészségkárosító hatással van, öten enyhén vagy közepesen egészségkárosító hatást tulajdonítanak az atomerömünek, s tízből mindössze egy gondolja, hogy nincs ilyen hatása.

Ha felidézzük az Eurobarometer megállapításait a villamos energiával kapcsolatos elvárásokat illetően, látható, hogy régiónk lakói - különösen a Bács-Kiskun megyé- 
ben élők - nagyon rosszul tájékozottak azokban a kérdésekben, amelyek számukra leginkább meghatározzák egy adott energiafajtához füződő viszonyukat.

$\mathrm{Az}$ elektromos áramellátással szembeni lakossági elvárások között első helyen az ár, második helyen az ellátásbiztonság, harmadikon pedig a környezetvédelmi szempontok állnak (Attitudes towards... 2006). A felmérés értékelésében nem mehetünk tovább anélkül, hogy ne végeznénk összehasonlítást e szempontok szerint a nukleáris és a megújuló energiaforrások között, hiszen így tủnik ki igazán a tájékozottság hiánya. A reális összevetés azért is fontos, mert mint a későbbiekben látjuk, éppen e két energiaforrással kapcsolatban áll legmesszebb a lakosság ismerete a valóságtól.

\section{Atom kontra megújulók}

Az atomerömủ 2006-ban 8,69 Ft-ért, míg a megújulók 23 Ft-ért állítottak elő $1 \mathrm{~kW}$ energiát, tehát majdnem háromszoros áron. Ha már megvalósul az ÜH és a teljesítménynövelés, akkor az atomenergia fajlagos költsége még tovább fog csökkenni, kb. 1,5 Ft-tal kW-onként.

Az ellátásbiztonság tekintetében is sokkal sérülékenyebb hazánkban a megújuló energiaforrások rendelkezésre állása. Sajnos nem rendelkezünk jelentős vízi energia potenciállal, a szélenergia kihasználtsági mutatója maximum $20 \%$ körül van, és nem tervezhető, valamint a villamos hálózatba kapcsolása komoly rendszerirányítási feladatot jelent, mert az csak korlátozott mennyiségben képes tolerálni a szélenergiát (Bessenyei-Kádár-Kazai 2007). Ezzel szemben az atomerömüben előállított energia jól tervezhető, s közel 90\%-os rendelkezésre állást mutat. Az atomerőmủ két évre elegendő üzemanyagot tárol mindenkor az erömüben, ami azt jelenti, hogy bármilyen külső konfliktus esetén is két évig képes ellátni a lakosságot, a fontosabb közüzemeket, iskolákat, kórházakat, élelmiszer előállító vállalatokat villamos energiával.

Hazánk biomassza potenciálja jelentős, a mai 4,5\%-ot kitevő megújuló energiaforrás-aránynak legnagyobb részét ez adja, ugyanakkor még „,zöld oldalról” is rengeteg kritika éri. Sokan megkérdőjelezik, hogy valóban zöldenergia-e az, amikor erdőket tarvágással termelnek ki, hogy alapanyagot szolgáltassanak a biomasszaerómúveknek. A BME vizsgálatai szerint $1 \mathrm{MW}$ kapacitás fenntartásához $35 \mathrm{~km}^{2}$ területre van szükség (Bajnóczy 2007). Ha az ország teljes területét erre használnánk, akkor is „csak” 2657 MW kapacitást tudnánk létesíteni.

Környezetvédelmi szempontokat figyelembe véve megállapítható, hogy hulladékképződés szempontjából a valódi megújulók kedvezőbb képet mutatnak, hiszen a nukleáris hulladék komoly kezelést, tárolást igényel. Látni kell ugyanakkor, hogy e hulladék mennyisége nem jelentős az előállított villamos energia volumenéhez képest. Megfelelő technológiával jól kezelhető. Rövidesen elkészül a bátaapáti hulladéktároló (melynek bỏvíthető kapacitása az esetleges új blokkok hulladékát is képes befogadni és biztonságosan tárolni), s jól haladnak a kutatások a kiégett kazetták tárolására alkalmas telephellyel kapcsolatban is. (A kiégett kazetták tárolása 2047-ig megoldott az erőmü területén). A kibocsátásokat tekintve megállapítható, hogy sem a valódi megújulók, sem az atomenergia nem jelent jelentős kibocsátást. 
A ma egyik legfontosabbnak tekintett $\mathrm{CO}^{2}$ kibocsátást vizsgálva is elmondható, hogy közel nulla az emisszió. A nagy különbség a két energiafajta között (környezetvédelmi szempontból) a volumen. Az atomerőmü évente 5,6-10 milliárd tonna széndioxid kibocsátást takarít meg (szén vagy modern gáz erőmühöz képest), a megújuló források - egyelőre - lényegesen kisebb mértékben képesek hatni a széndioxid kibocsátás csökkentése érdekében.

\section{Nukleáris és megújuló energiaforrások}

E rövid összehasonlító fejezetrésszel nem az a célunk, hogy a „megújulók kontra atom" vitát élesítsük. Éppen ellenkezőleg: a két forrás együittes erősítése tuđja csak felvenni a versenyt a klímaváltozás ellen. Remélhetöleg a jövőben a megújulók olyan mértéket érhetnek el villamosenergia-felhasználásunkból, hogy igényeink kielégítésének đöntỏ részét rájuk bízhatjuk. Azonban belátható időn belül ez az arány nem lesz elegendỏ ahhoz, hogy globális szinten csökkentse a $\mathrm{CO}^{2}$ kibocsátást. Addig pedig nagy szükség lesz az atomerömúvekre, hiszen ez az egyetlen olyan forrás, mely nagy mennyiségủ villamosáram-elóállitására képes üvegházhatású gázok kibocsátása nélkül.

Az energetikai szakemberek ezt már régóta tudják, s ma már a politikusok többsége is kezdi belátni. Magyarországon van némi lemaradás, hiszen míg pl. NagyBritannia 2006 áprilisa óta viseli a kormány tagjai által lebonyolított utak szennyezési költségét - a kormány 2007-09 között a tervek szerint mintegy 3 millió fontot (1,5 milliárd forintot) költ erre a célra -, addig a magyar Parlamentben a klímaváltozás szó négyszer, az éghajlatváltozás ötször hangzott el a 2006/07 ciklusban az országgyülési napló szerint.

Várható persze, hogy a közeljövőben nálunk is rendszeres beszéđtéma lesz a Parlamentben a klímaváltozás. Nagyon fontos, hogy a polgárok megfelelő tájékoztatást kapjanak a valós helyzetről, a lehetőségekröl, hiszen a felmérések is mutatják, hogy nagyon keveset tudnak az emberek a témával kapcsolatban, és azt is többnyire roszszul. A bulvársajtó a radikális zöldek akcióiról tudósít, kétes értékü „szakértők” kétes értékủ ,szakvéleménye” formálja (vezeti félre) a polgárok véleményét.

A lakosság nem csekély részéhez csak a ,szél ingyen fúj, a nap ingyen süt” szintü információk jutnak el. A hazai polgárok többsége nincs tisztában a megújuló energiák beruházási és üzemeltetési költségeivel, azok gyenge versenyképességével, a szükséges állami támogatások mértékével (évi több tízmilliárd forint) és a támogatások áremelỏ hatásaival. Azt sem tudják, hogy a megújuló energiaforrások egy része kevéssé képes követni a gyorsan változó energiaigényt, és hogy ebből komoly ellátási gondok adódnak. Sajnos a tájékoztatási hiányosságokhoz sok jó szándékú környezetvédő is hozzájárul. Ezért nagyon fontos lenne, hogy a kormányzat, az energetikai szakma, az egyetemek és a hazai tudományos közösség közérthetően megfogalmazott és objektív szakmai információkat készítsen, és azokat rendszeresen eljuttassa a nagyközönségnek. A VAHAVA (változás - hatás - válasz) projekt figyelemre méltó 
kutatásokat folytat e témakörben, konkrét veszélyekre hívja fel a figyelmet (Láng 2005), ugyanakkor a közvélemény - egyelőre - sajnos keveset tud az eredményekröl.

A PA Zrt. eddig remekül oldotta meg feladatait, akár műszaki, gazdasági vagy tájékoztatási feladatról legyen is szó, mindig megfelelően alkalmazkodott a helyzethez. Most új kihívással kell szembenéznie. Az elmúlt évek energiaellátási gondjai (gáz-, illetve olajszállítási problémák), valamint a világból jövő hírek a globális felmelegedésről, megrendítették az emberek bizalmát a fosszilis energiaforrásokkal szemben. A közvélemény gyorsan reagált, jelentősen lecsökkent a gázt preferálok száma, s nagyon megugrott a megújulókat támogatók aránya. Olyan, mintha a „megújuló” egy varázsszó lenne. A kőolaj- és a gázellátási gondokkal kapcsolatban ellenpéldaként - néhány nagyon ritka kivételtől eltekintve - a megújulókat említették. Ez eredményezhette, hogy a megújuló energiaforrások nemcsak a fosszilisoktól, hanem az atomenergiától is szereztek támogatókat. Az atomerómü körüli térségben összesen $10 \%$ ponttal kevesebben gondolják a két évvel korábbihoz képest azt, hogy az atomerómú termeli legolcsóbban a villamos energiát, s mint az Eurobarometer felméréséból kiderült, a vélt olcsóság és a támogatottság között szoros a kapcsolat.

Korábban már felvetettük, hogy várható a politika aktivizálódása az ügyben, így a jövőben még több szó esik majd a globális felmelegedés veszélyeiröl.

Ez lehetőséget jelent az atomerőmú számára, hogy kiemelje saját érdemeit és lehetőségeit a klímaváltozás elleni harcban, de egyúttal veszélyt is rejt magában, amenynyiben tovább folyik a megalapozott tudásnélkülieknél a „megújulók” elöretörése.

A vizsgálati eredmények segítséget nyújtanak abban, hogy milyen területeken lehet hatékony kommunikációt folytatni, azonban a célpiac pontos szegmentációjára nem alkalmasak, ez egy további kutatás keretei között valósulhat meg.

Ez a vizsgálat ugyanakkor egyértelmủ kapcsolatot mutatott ki a tájékozottság és az atomerőmü támogatottsága között. Tehát elemi érdek a tudásszint növelése. A tudásszintet tekintve lényeges különbségeket állapítottunk meg egyes alcsoportok kőzött. Minden kérdésre igaz, hogy a Duna jobb partián lényegesen nagyobb a tudás (s ezzel együtt a támogatottság is), mint a másik oldalon. Hasonló eltérést figyelhetünk meg az iskolai végzettség, illetve a nemek szerinti csoportosításnál, pl. az üvegházhatásért felelősnek tartják az atomerömüvet a Dunántúlon 42\%-ban, az Alföldön $64 \%$-ban. A férfiak 44\%-a, a nók 56\%-a gondolja ugyanezt. A diplomások közül $31 \%$, míg az alacsonyabb végzettségúek $52-58 \%$-a szerint bocsát ki az atomerőmü klímaváltozásért felelős gázokat. Hasonló különbségeket találtunk a TEIT és a nem TEIT településen élök tudásszintje között, ha nem is ilyen mértékben (47-54\%). 


\section{3. ÁBRA}

Az atomerőmü és az üvegházhatás

(The Nuclear Power Plant and the Greenhouse-effect)

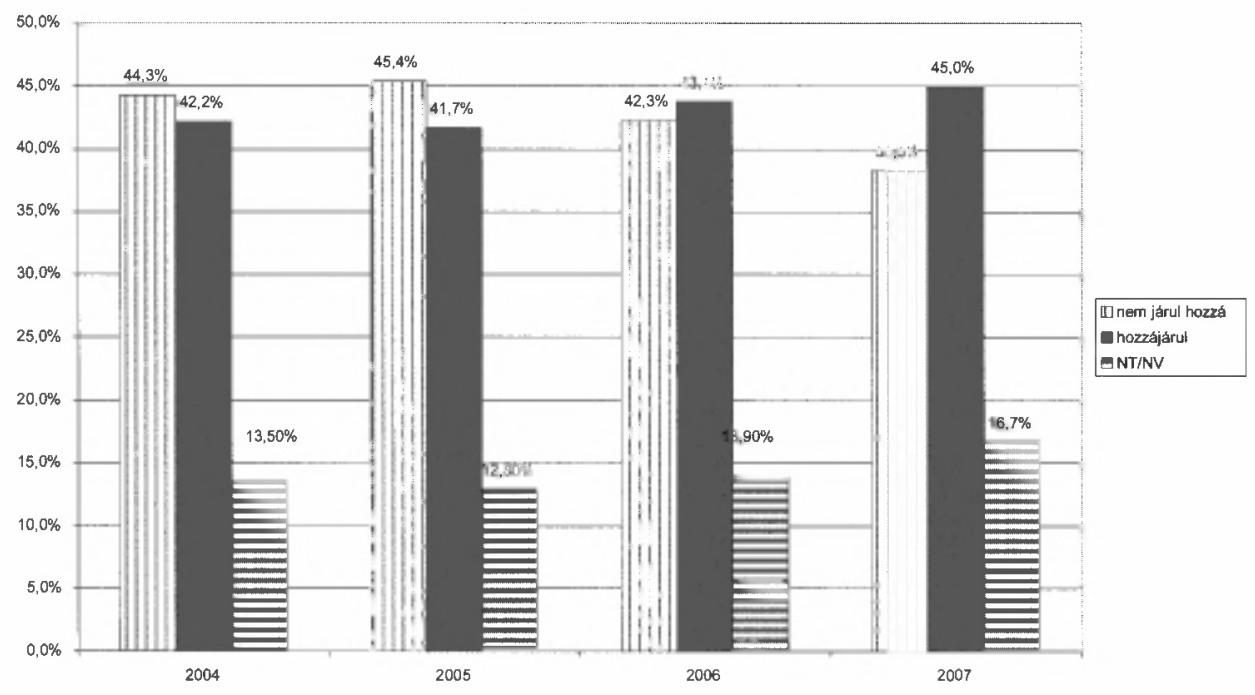

Forrás: Szociográf (2006).

Öt, „tárgyi tudást” igénylő kérdésre adott válaszok alapján megvizsgáltuk, milyen kapcsolat mutatható ki az ismereti szint és az atomerőmủvel, annak mủködésével kapcsolatos attitüdök között. A számítások részleteit terjedelmi okok miatt mellőzzük, csak a következtetést vonjuk le: Lényegesen magasabb szintủnek bizonyultak azoknak az ismeretei, akik egy népszavazás alkalmával támogatnák a paksi atomerőmü üzemidejének meghosszabbítását, mint akik elleneznék azt.

A tudásszint növelésére alkalmas médiumok kiválasztására megvizsgáltuk, milyen csatornákon keresztül várnak információkat megkérdezetteink, illetve milyen elvárásaik vannak az üzemidő hosszabbítási program előkészítésével kapcsolatosan. A válaszadók majdnem fele $(49,3 \%)$ az erómủ illetékes szakembereit jelölte meg, a TV, rádió $36,3 \%$-ot kapott.

\section{Munkalehetőség}

Ez központi téma a túloldalon élök körében. Már korábban utaltunk rá, hogy 2007 elején a 2800 erőmủves dolgozó közül mindössze 5 élt a Duna bal partján. A közeljövőben történő infrastrukturális fejlesztések (M6) elérhetőbbé teszik az erỏmủvet, mint munkahelyet. Ma átlagosan fél óra alatt érnek be a „túlsóféliek”, és ez országos viszonylatban, vagy Budapesten elviselhetö időnek számít.

Az atomerőmủ napjainkban, a piacliberalizáció jegyében, versenyképességének növelésén fáradozik, igyekszik - humánus módon - csökkenteni dolgozói létszá- 
mát, ez nyilvánvalóan nem kedvez az esetleges új felvételeknek. Ugyanakkor a megvalósuló üzemidő-hosszabbítás s az erőmü korfája - igen jelentős a közeljövőben nyugdíjba vonulók száma - akár középtávon, néhány év múlva is jelentős munkaeröhiányt generálhat. Esetleges új blokkok építése pedig még komolyabb munkalehetőséget jelent a környéknek. Amennyiben zöld utat kapna a bővítés, akkor az kb. 2080-ig jelenthetne munkalehetőséget a környék lakosainak, tehát akár a ma középkorúak unokái is dolgozhatnának itt. Ez ma még csak teoretikus jelentöségü, azonban meg kell teremteni annak a lehetőségét, hogy amennyiben valóban megjelenik a munkaeröigény, ennek egy részét a Duna bal partján élök fedhessék le.

A Duna bal partján élők jelenleg úgy érzik, hogy ki vannak rekesztve egy jól fizető munkaerőpiacról, s ez nyilván ellenérzéseket táplál átvitt értelemben az atomenergiával szemben is. Ha a lehetőség megnyilna, akkor sem biztos persze, hogy sokan vállalnák az utazást $\mathrm{s}$ a sok tanulást, de vélhetően sokat oldana az ellenszenvböl. Egy ösztöndíjrendszer, mely minden település iskolájából évfolyamonként a matematikából-fizikából legjobb tudású diákot támogatná, s lehetőséget biztosítana neki egy sikeres múszaki életpálya kialakítására, egy kis településen, melyek - Kalocsa kivételével - jellemzik az érintett területeket, várhatóan erósen pozitív hatással lenne az erömü megitélésére.

Egy további vizsgálat választ adhatna az imént felvetódött kérdésekre. Hasznos lenne egy vizsgálat keretében kérdést intézni az ott élőkhöz, hogy például, mit szólna, ha gyermeke, rokona dolgozna az erőmüben.

E kérdéssel információt kaphatnánk arról, hogy valóban jelentós félelmek uralkodnak-e a lakosság körében az erömüvel kapcsolatban, hiszen a saját gyermekét csak biztonságos munkahelyre engedné el szívesen mindenki. A kérdésre adott válasz megmutatná, merre induljunk tovább a tájékoztatás tekintetében. Ha a többség nem örülne gyermeke atomerömúves munkavállalásának, akkor az azt jelenti, hogy további energiákat kell a félelem csökkentésére fordítani. Ha viszont az emberek többsége örüilne gyermekei erőmüves munkalehetöségének, akkor meg kell vizsgálni, milyen lehetőségek vannak közép- és hosszú távon arra, hogy a „túlsóféliek” is bekapcsolódjanak az erőmű munkavállalói körébe. Itt nem ígéreteket kell tenni, hanem a lehetőségeket megnyitni.

\section{Egészségügyi kérdések}

Még mindig vannak olyan vélekedések a településeken, hogy az erőmú múködése daganatos megbetegedést okozhat. Ennek feloldása szintén tájékoztatási feladat, hiszen a szakmai vizsgálatokat már elvégeztük. Megfelelóen kell ismertetni a legfrissebb eredményeket, melyek szerint az erőmü környezetében az országos átlag alatt van e megbetegedések száma. A vizsgálat közel húsz év adatait használta fel, több ezer ember egészségügyi eredményeit vizsgálta. A vizsgálati eredményeket egy 170 oldalas tanulmányban foglalták össze (A paksi.. 2005). Az eredmények magukért beszélnek. A daganatos megbetegedések száma az erömü környékén az 
országos átlag alatt van. Természetesen a tanulmány nem tulajdonít pozitív hatást az erőmünek, egyszerúen megállapítja, hogy nincs összefüggés az atomerőmü múködése és a daganatos megbetegedések alakulása között.

\section{A polgármesteri hivatalok müködése}

A vizsgálatok felhívták a figyelmet a polgármesteri hivatalok múködésének hiányosságaira is. Hiába támogatja az erőmű a térséget évröl évre sok millió forinttal, az ott lakók elenyésző számban tudtak csak megnevezni konkrét programokat, segítségnyújtást, támogatást, ami az erömü közremüködésével érkezett az adott településre. A térség éves szinten $\mathrm{kb}$. 300M Ft támogatást kap, melyet öneröként felhasználva, további pályázatokkal 1 milliárd körüli pénzt mozgat meg. A gyakorlat szerint - néhány kivételtől eltekintve - az önkormányzathoz befolyt támogatást már úgy használja fel a polgármester, hogy az ,atomerömüves címke” lemarad róla. Így, akik a támogatás haszonélvezői, azok sincsenek tisztában azzal, hogy a segítség számukra az atomerőmủből érkezett. Az érintett településeken a lakosságnak mindössze 8\%-a tudott konkrét atomerömủ általi támogatást nevesíteni. A támogatások jobb nyomon követése, illetve az erómü segítségének hangsúlyozása, tudatosítása segíthetne a szimpátia megerősitésében.

\section{Összefoglalás}

A 2007-es Nobel-békedijat Al Gore volt amerikai alelnök és a klímaváltozás problémájával foglalkozó kormányközi szervezet (IPCC) kapta megosztva. Ez jelzi, hogy tudományos körökben már felismerték a globális felmelegedés veszélyeit, s a kibocsátások csökkentésẻnek fontosságát. Eközben a világ energiafelhasználása töretlenül emelkedik, további szennyezés-növekedés veszélyét indukálva. A politikai elit megtette az első komolyabb lépéseket, hiszen pl. az Európai Unió célkitüzései között 2020-ig 20\%-os széndioxid kibocsátás csökkentés szerepel. A növekvő energiaigény és a csökkenő kibocsátások iránti elkötelezettség együttes megoldása csak a megújuló energiaforrások lehetőség szerinti bővülése és az atomenergia markáns térnyerése által lehetséges. Az atomenergia felhasználása ugyanakkor társadalmi elfogadottsághoz kötött, így hiába tudják a szakemberek, a szakpolitikusok és a döntéshozó politikusok is, hogy a nukleáris energia nélkül nem lehet eredményeket elérni a klímaváltozás megállításában, a végső szót egy demokráciában a közösség hozza meg. Ahhoz, hogy a közvélemény a helyes utat támogassa, nagyon fontos, hogy véleményük kialakításához a megfelelö tájékoztatást megkapják. Minden társadalmi rétegnek a saját szintjén, a megfelelö csatornákon kell eljuttatni az információkat. Tennünk kell azért, hogy ha eljön az idő, hogy Magyarországon dönteni kell az atomenergia jövöjérooll, akkor a Duna bal partján élök, úgy is, mint Magyarország polgárai, $\mathrm{s}$ úgy is, mint az atomerömü közelében élö emberek saját érdekükben támogassák a számukra legkedvezőbb energiaforrást, a nukleáris energiát. 


\section{Irodalom}

Attitudes towards Energy. (2006) Eurobarometer.

Attitudes on issues related to EU Energy Policy. (2007) Eurobarometer.

Bajnóczy G. (2007) Magyarország lehetóségei a megújuló erôforrásokban. Energetikai Szimpózium. Szent Ignác Szakkollégium, Budapest.

Bessenyei T.-Kádár P.-Kazai Zs. (2007) A „mini megújulós” kapacitós integrációja a magyar villamos energia rendszerbe. Energia Klub, Budapest.

Csom Gy. (2006) A nukleáris energia szerepe a jövö energiaellátásában, különös tekintettel a paksi atomerómü jövöjére. Kézirat. Budapest.

Csom Gy. (2007) Energiapolitikia prioritások. - Magyar Tudomány. 1. 4-10. o.

Elter E.-Katona T.-Kovács F.-Kovács A. (2006) A nukleáris energia tảrsadalmi értékelése. II. Kárpátmedencei Környezetvédelmi Konferencia, Pécs.

Energy Technologies: Knowledge, Preception, Measures. (2007) Eurobarometer.

Felmérés az energiaforrások és a Paksi Atomerõmü Zrt. lakossági megitélésérõl. (2006) TNS, Paks.

Kováts B. (2006a) Alliances of Nuclear Municipalities in Hungary. Nea Forum on Stakeholder Confidence. Tengelic.

Kováts B. (2006b) Evolution of Supports. NEA Forum on Stakeholder Confidence. Tengelic.

Láng I. Bevezetỏ gondolatok a klímaváltozás kockázatához. - Magyar Tudomány. 7. 786-788. o.

A paksi atomerỏmủ élettartam hosszabbitásának és teljesítménynövelésének környezetvédelmi és vízjogi engedélyezéséhez kapcsolódó telephely-jellemzési program: A hatásterület daganatos morbiditási és mortalitási viszonyainak elemzése. (2005) Paksi Atomerőmũ Zrt. Budapest.

A Paksi Atomerõmü és az energiaforrások lakossági megitélése. Összehasonlitás 2004-2005-2006. (2006) Szociográf, Paks.

Poós M.-Rátz L. (2005) A hazai energiaellátással kapcsolatos közép és hosszú távú környezetvédelmi követelmények. Kézirat, Budapest.

Radioaktiv waste. (2005) Eurobarometer.

Regionális felmérés az energiaforrások és a Paksi Atomerômü Zrt. lakossági megitélésérōl. (2006) Szociográf, Paks. 